\title{
Show me a man or a woman alone and I'll show you a saint: Changes in the frequency of criminal incidents during the COVID-19 pandemic
}

\author{
Tarah Hodgkinson ${ }^{\mathrm{a}, *}$, Martin A. Andresen ${ }^{\mathrm{b}}$ \\ ${ }^{a}$ School of Criminology and Criminal Justice, Griffith University, Mt Gravatt Campus, 176 Messines Ridge Road, Mt Gravatt, QLD 4122, Australia \\ ${ }^{\mathrm{b}}$ School of Criminology and Criminal Justice, Griffith University, Gold Coast Campus, Parklands Dr, Southport, QLD 4215, Australia
}

\section{A R T I C L E I N F O}

\section{Keywords:}

Pandemic

Extraordinary event

Crime

COVID-19

Canada

\begin{abstract}
A B S T R A C T
Objectives: To investigate the effect of the COVID-19 pandemic on the frequency of various crime types (property, violent, and mischief) in Vancouver, Canada.

Methods: Crime data representing residential burglary, commercial burglary, theft of vehicle, theft from vehicle, theft, violence, and mischief are analysed at the city level using interrupted time series techniques.

Results: While COVID-19 has not had an impact on all crime types, statistically significant change has been identified in a number of cases. Depending on the crime type, the magnitude and direction of the change in frequency varies. It is argued that (mandated) social restrictions, shifted activity patterns and opportunity structures which are responsible for these findings.

Conclusions: We find support for changes in the frequency of particular crime types during the COVID-19 pandemic. This is important for criminal justice and social service practitioners when operating within an extraordinary event.
\end{abstract}

\section{Introduction}

The nature of social life has changed as a result of COVID-19. Emerging out of Wuhan, a city of over 11 million people in the province of Hubei, China, the highly infectious respiratory illness quickly spread to other parts of the globe (Readfern, 2020). Within a few months of the start of 2020, several nations locked down in an attempt to prevent the spread of the virus in an increasingly globalized world. Borders were closed, travel was restricted, businesses were shuttered, and everyone was advised to wash their hands and "\#stayhome." The nature of work and the economy changed dramatically.

COVID-19 led to an unprecedented shift in the social structure of global cities. As the world went into isolation, social life transformed. In many parts of the world, only essential workers (health care providers, front-line officers, food services, etc.) were permitted to leave their homes to work. Others were instructed to stay home except for health care, exercise, or a weekly trip for groceries. In many countries social gatherings were banned, and the streets emptied.

The research on crime and exceptional events (natural disasters, terrorist attacks, riots, and pandemics) has demonstrated that a shift in collective behavior can also lead to shifts in criminal behavior (Barton, 1969; Drabek, 1986). While several explanations are offered for this shift in criminal behavior, we suggest that as the opportunity structure for crime changes, so too does the prevalence of crime. Exceptional events, like a pandemic, act as a natural experiment, because they change the structure of routine activities that can reorganize how offenders, victims, and capable guardians converge in time and space. For example, if people are staying at home, their guardianship over their residence would improve making these targets more difficult to victimize. Alternatively, as work and life shift online, new targets or victims may emerge for motivated offenders. Certain types of violent crime may increase (e.g. domestic violence) as the offender and victim converge for longer periods of time, while other crime types may decrease (e.g. robbery and assault) as offenders and victims are unable to converge in the same way as before the event.

The current study explores the shift in criminal behavior across crime types in Vancouver, Canada during the shutdown period in early 2020. Canada, operating under a liberal government, moved very quickly to close borders and help Canadians abroad return home. Canada was well positioned to address COVID-19 quickly. In 2003, after the SARS epidemic, a number of recommendations were made to better prepare Canada for future health crises. Importantly, this included the creation of the Public Health Agency of Canada, which led the response to COVID-19 in 2020, including rapid response plans to isolate Canadians (Webster, 2020). The SARS outbreak also resulted in Canada's federal emergency law - The Quarantine Act - passed in 2005,

\footnotetext{
* Corresponding author.

E-mail addresses: t.hodgkinson@griffith.edu.au (T. Hodgkinson), m.andresen@griffith.edu.au (M.A. Andresen).
} 
which can allow the federal government to quarantine Canadians. This means that Canada went into lockdown efficiently and, arguably, effectively in comparison to other nations.

This creates an opportunity to explore the preliminary effects of this lockdown on crime trends in one of Canada's major cities, with the intention of determining if the shift in opportunity structures have changed crime trends and to improve planning for safety and crime prevention for potential further outbreaks of the pandemic and future exceptional events. This research contributes to a growing literature on crime trends and exceptional events, suggesting that addressing the opportunity structures presented by particular exceptional events, the social costs of these events can be reduced.

\section{Related literature}

\subsection{Exceptional events}

Exceptional events, such as natural disasters, riots, blackouts, and pandemics are unusual incidents that often result in a significant shift in human behavior. These events create an opportunity to explore our understandings of the world. In particular, as the social order shifts and human behavior shifts with it, these events enable us to test the bounds of social theories and policies (Andresen \& Tong, 2012; Barton, 1969; Drabek, 1986). These incidents are acute, stressful, often unanticipated, and can disrupt the informal regulatory processes of social life (Ritchie \& Gill, 2011). While the effects can sometimes be transitory, some exceptional events can have long term impacts on both population composition and behavior in affected communities.

Exceptional events usually fall into three spheres, the lithosphere, atmosphere and biosphere (Tipson, 2013). Lithosphere events include changes to the earth's crust which can cause volcanic eruptions, earthquakes, and tsunamis. Atmosphere events involves temperature changes in the water or air that can result in droughts, wildfires, hurricanes, tornadoes, and floods (Tipson, 2013). Pandemics, such as COVID-19, are biosphere disasters in which microorganisms can shift or evolve and potentially lead to a significant loss of life.

Biosphere disasters also emphasize the vulnerabilities of social and political systems, including access to health care, safety and economic security. These exceptional events can result in competition and hoarding, social instability and unrest, and competition for health care and vaccines (Tipson, 2013). COVID-19 has exposed the impacts of a succession of neoliberal governments in the western world as political leaders fight for access to ventilators and masks (Martin, 2020), vulnerable citizens lack access to social safety nets and protections, and others are forced to work for inadequate compensation while putting their lives on the line (North, 2020). These situations make it difficult to respond to needs in an efficient and effective way, devoid of corruption. Indeed, the world has already witnessed the extent of corporate greed and disaster/monopoly capitalism (Klein, 2007; Robinson, 1933) as CEOs capitalize on insider information to sell off stock and prey on small businesses unable to weather the economic impact of a global shut down (Neate, 2020).

\subsection{Theoretical explanations of fluctuating crime rates and exceptional events}

There are three main theoretical explanations of how crime emerges or shifts during an exceptional event. These theoretical explanations include social cohesion and altruism, social disorganization, and opportunity theories. Interestingly, these explanations produce contradictory predictions about crime trends during an exceptional event.

Social cohesion, or altruism theories, predict that crime rates decline or remain stable during an exceptional event (Zahran, Shelly, Peek, \& Brody, 2009). This argument has largely emerged from natural disaster research, in which proponents of the theory argue that during an emergency, people are more likely to help each other and act altruistically (Barton, 1969). For example, Quarantelli (2007) argues that an increase in opportunistic crime, such as looting or theft, is rare after a disaster. After the 1994 earthquake in Los Angeles, violent crime did not increase (Siegel, Bourque, \& Shoaf, 1999). Furthermore Sweet (1998) found a temporary increase in the levels of social support and cohesion after the ice storm in New York in January 1998. A similar situation occurred the same year in Quebec, Canada, in which the ice storm there led to electrical blackouts. Lemieux (2014) found that property crime dramatically decreased as instrumental altruism (government financial support) increased.

However, this theoretical perspective has been heavily critiqued as many groups do not receive equal assistance during exceptional events such as earthquakes, ice storms, or blackouts. Indeed, Fothergill and Peek (2004) found that exceptional events often exacerbate social inequality. This was evident in the lack of support provided to non-white Americans in the aftermath of Hurricane Katrina (Craemer, 2010). Furthermore, exceptional events can lead to changes in police reporting practices as front-line officers redirect their efforts to other, more pressing, issues (Barsky, Trainor, \& Torres, 2006), and this can affect crime trends more broadly. This is particularly the case in natural disasters where the police role is expanded.

Another theoretical explanation of crime in exceptional events is social disorganization theory, which would predict an increase in crime rates as the social order is disrupted. As mentioned, exceptional events tend to exacerbate social inequality and emphasize the disadvantage of certain groups. Advocates of this explanation argue that social cohesion and collective efficacy are not strengthened by an exceptional event, but rather weakened. In turn, these systems are unable to control antisocial behavior (Curtis, Miller, \& Berry, 2000; Davila, Marquart, \& Mullings, 2005; Harper \& Frailing, 2012; Prelog, 2016). For example, in the New York City blackout in 1977, Genevie et al. (1987) found increases in looting in neighborhoods that already had higher levels of violent crime, illicit economy activity, and unemployment. However, in their study of the floods in Brisbane in 2011, Zahnow, Wickes, Haynes, and Corcoran (2017) found a displacement effect (in which crime incidents move from one location to another) for property crime to affluent, non-flood affected neighborhoods, suggesting that crime may shift as opportunity changes.

This leads us to the final theoretical explanation, which accounts for the variations in findings from the other two theoretical perspectives. Opportunity theories, such as routine activities theory, would predict that during an exceptional event, crime rates will both increase and decrease depending on the crime type and the shift in opportunity structure (Leither et al., 2011). Routine activity theory argues that in order for a crime event to occur, a suitable target, a motivated offender, and the lack of a capable guardian need to come together in time and space (Cohen \& Felson, 1979). This theory emerged in response to the inability of other sociological and criminological theories to explain how a dramatic increase in financial prosperity had paralleled a dramatic increase in crime in the 1950s and 1960s in the United States. Cohen and Felson (1979) reasoned that the increase in crime was not a result of disadvantage or strain, but rather an increase in opportunities. Peoples' routine activities had changed. Entertainment options increased and this shifted people into the public sphere. Women moved into the workforce in droves and were no longer at home to act as capable guardians. There was also an increase in the manufacturing and proliferation of lightweight durable goods that were cheaper to purchase and easier to steal (Felson \& Cohen, 1980).

This research suggests that as the balance between suitable targets, motivated offenders, and capable guardians shift, this will have an indirect effect on crime trends (LeBeau, 2002). Exceptional events can increase or decrease target availability by destroying, moving, or shifting targets (Zahran et al., 2009). For example, as capable guardianship decreases, as people leave their homes during a flood or hurricane, opportunities for burglary may increase (LeBeau, 2002). Opportunity theories can also explain an increase in altruism as a 


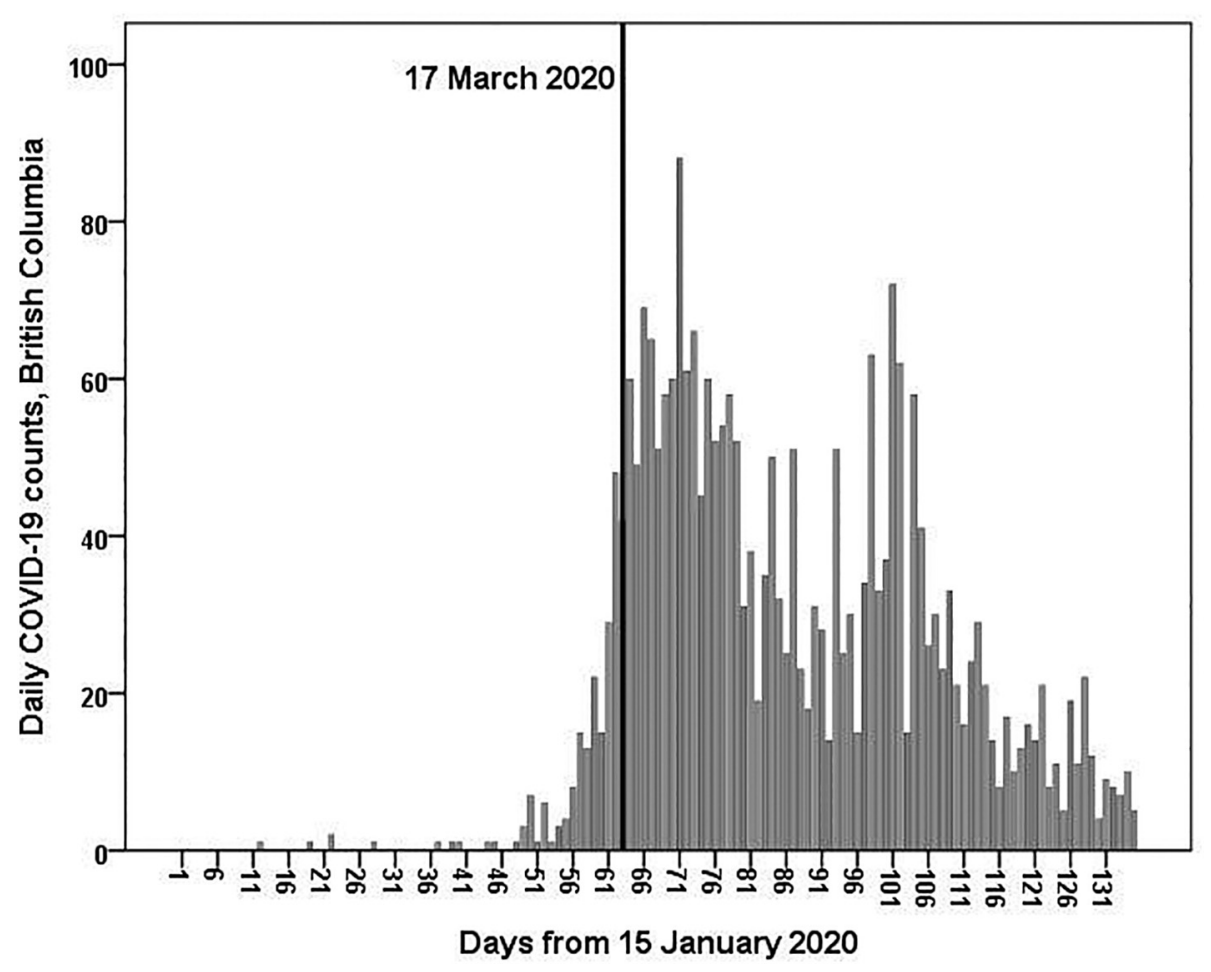

Fig. 1. COVID-19 daily infections, British Columbia.

protective factor against crime through the creation of informal guardianship (Curtis \& Mills, 2011). In the aftermath of Hurricane Andrew in Florida, in 1992, informal control mechanisms emerged to protect these properties (citizen-led patrols), which prevented an increase in opportunities and, in turn, property crime (Cromwell, Dunham, Akers, \& Lanza-Kaduce, 1995). Research on the long-term trends of crime after an exceptional event also suggest that when the opportunity structure returns to its pre-event status, crime trends in the affected areas also return to pre-event levels (Zahnow et al., 2017).

\subsection{Exceptional events and crime}

Exceptional events can have an important impact on crime. As the social composition of the community changes, so too can crime rates. The research on the impact of exceptional events on crime rates explores hurricanes, floods, earthquakes, blackouts, and more. However, as noted above, the findings of this research are mixed. For example, in 1989, Hurricane Hugo resulted in a higher rate of property crime (Quarantelli, 2007). Hurricane Katrina, in 2005, also led to a significant increase in burglary rates (Harper \& Frailing, 2012). However, Varano, Schafer, Cancino, Decker, and Greene (2010) found that violent crime rates, such as robbery and homicide, did not change in the aftermath of Hurricane Katrina. In fact, they demonstrated that the increase in other crimes was a result of a shift in population, because a large number of survivors moved into one area. Leitner, Barnett, Kent, and Barnett (2011) and Leitner and Helbich (2011) found that crime rates after Hurricane Katrina remained relatively stable or even declined. Hurricane Rita, which hit later that same year, resulted in an increase in burglaries. Interestingly, this increase did not occur after the hurricane hit, but after the evacuation notice was given (Leitner \& Helbich, 2011).

Changes in crime trends in exceptional events are not limited to hurricanes. The electricity blackouts in 1965 and 1977 in New York City led to dramatically different experiences of crime. The 1965 blackout had a negligible impact on crime rates (Farrell, 1965: Montgomery, 1965), while the 1977 blackout resulted in an increase in property crime and arson (Corwin \& Miles, 1978). The earthquakes in
Christchurch, New Zealand in 2010 and 2011 resulted in a significant decline in crime in the Central Business District (CBD) after the earthquake, in particular where alcohol outlets had disappeared. However, a displacement effect occurred to some areas outside of the CBD that were not hit as hard by the earthquake and where alcohol was still available (Breetzke \& Andresen, 2018). During the flood in Brisbane, Australia in 2011, Zahnow et al. (2017) found that crime fluctuated across neighborhoods during the flood but returned to previous levels soon after the event was over. Similarly, a flood in Nigeria in 2012, that killed ten times the number of people compared to Brisbane and displaced over 2 million others, led to an increase in violent crime rates. However, these rates also returned to pre-existing levels after the disaster (Kwanga, Shabu, \& Adaaku, 2017).

The research focusing on the effects of pandemics on crime rates is relatively scarce. Importantly there is minimal criminological research about how pandemics affect other types of crime, such as corporate crime and corruption, cybercrime, and environmental crimes. At the time of writing, some research has emerged to say that the trends of certain crime types are changing. For example, Eisner and Nivette (2020) commented on the increase in hate crimes against East Asian persons and care providers. They also reported dramatic increases in domestic violence and child abuse (Eisner \& Nivette, 2020). McDonald and Balkin (2020) have found some increases in rape, arson, and auto theft in five major cities in the United States. Mohler et al. (2020), investigated crime in Los Angeles and Indianapolis, found that vehicle stops notably decreased and domestic violence was increasing. However, other crime types had minimal changes, and most were modestly decreasing. And Ashby (2020), in a study of 16 cities across the United States, found no increases in violent crime with mixed results for property crime. However, many of these preliminary findings require additional research. Shifting crime trends alone should not guide policy or practitioners. It is possible that these early changes could be an anomaly. It is necessary to explore both how crime rates may be changing, but also how these changes occur within the context of other controls such as seasonal and yearly trends. 
(a)

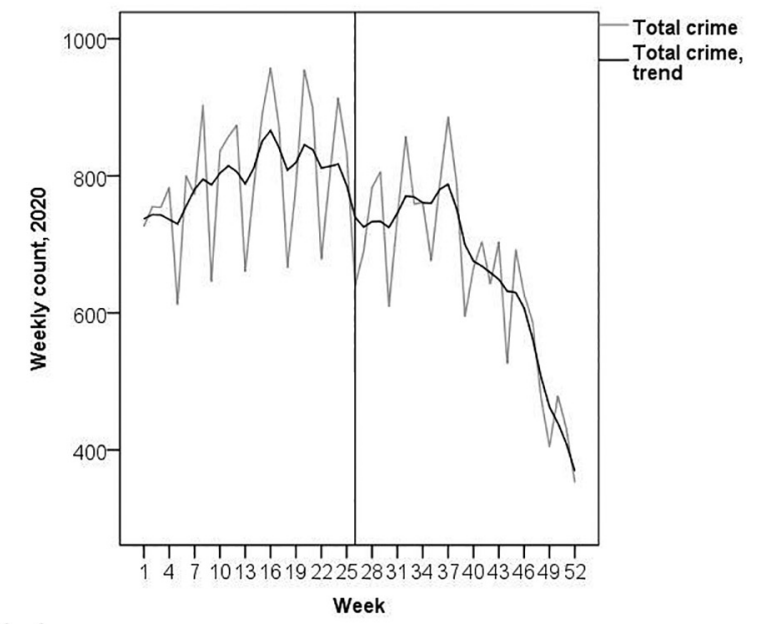

(c)

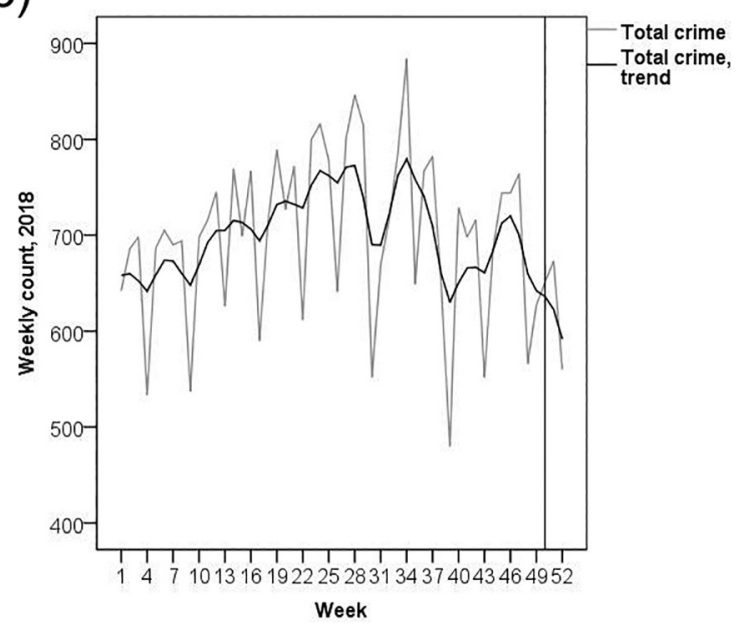

(b)

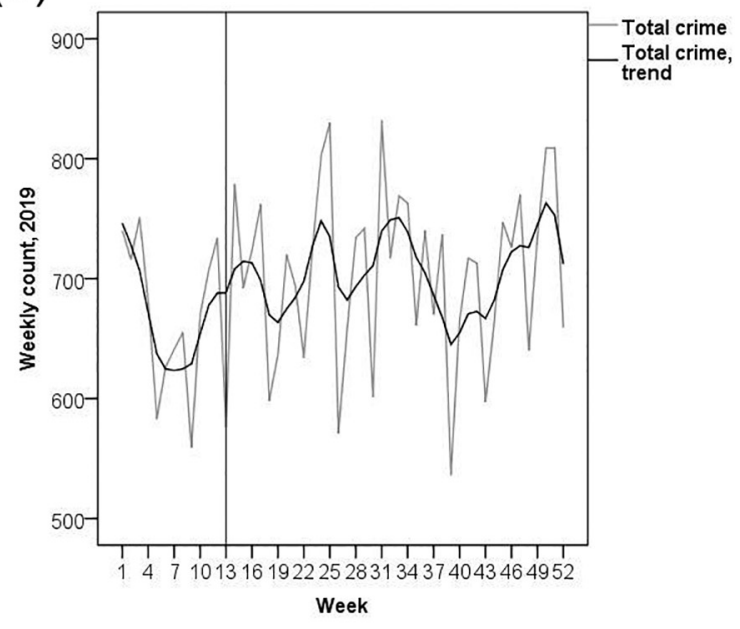

Fig. 2. Vancouver total crime trends.

Table 1

Interrupted time series summary

\begin{tabular}{|c|c|c|c|c|c|c|c|c|c|}
\hline 42 & & Total & Violence & Mischief & Theft of vehicle & Theft from vehicle & Theft & $\begin{array}{l}\text { Residential } \\
\text { burglary }\end{array}$ & Commercial burglary \\
\hline \multirow[t]{2}{*}{2020} & Week & 26 & 17 & 40 & 13 & 22 & 41 & 22 & 46 \\
\hline & Change & $\begin{array}{l}\text { Decreasing trend } \\
\text { week } 38\end{array}$ & $\begin{array}{l}\text { No obvious } \\
\text { change }\end{array}$ & $\begin{array}{l}\text { No obvious } \\
\text { change }\end{array}$ & $\begin{array}{l}\text { No obvious } \\
\text { change }\end{array}$ & $\begin{array}{l}\text { Decreasing trend } \\
\text { week } 40\end{array}$ & $\begin{array}{l}\text { Decreasing trend } \\
\text { week } 42\end{array}$ & $\begin{array}{l}\text { No obvious } \\
\text { change }\end{array}$ & $\begin{array}{l}\text { Increasing trend week } 42 \text {, } \\
\text { decrease week } 46\end{array}$ \\
\hline \multirow[t]{2}{*}{2019} & Week & 13 & 4 & 50 & 17 & 31 & 18 & 6 & 5 \\
\hline & Change & $\begin{array}{l}\text { Increasing trend } \\
\text { week } 39\end{array}$ & $\begin{array}{l}\text { No obvious } \\
\text { change }\end{array}$ & $\begin{array}{l}\text { No obvious } \\
\text { change }\end{array}$ & $\begin{array}{l}\text { Increasing trend } \\
\text { week } 42\end{array}$ & $\begin{array}{l}\text { No obvious } \\
\text { change }\end{array}$ & $\begin{array}{l}\text { No obvious } \\
\text { change }\end{array}$ & $\begin{array}{l}\text { No obvious } \\
\text { change }\end{array}$ & No obvious change \\
\hline \multirow[t]{2}{*}{2018} & Week & 50 & 50 & 7 & 31 & 4 & 5 & 8 & 7 \\
\hline & Change & $\begin{array}{l}\text { No obvious } \\
\text { change }\end{array}$ & $\begin{array}{l}\text { No obvious } \\
\text { change }\end{array}$ & $\begin{array}{l}\text { No obvious } \\
\text { change }\end{array}$ & $\begin{array}{l}\text { Increasing trend } \\
\text { week } 40\end{array}$ & $\begin{array}{l}\text { No obvious } \\
\text { change }\end{array}$ & $\begin{array}{l}\text { No obvious } \\
\text { change }\end{array}$ & $\begin{array}{l}\text { No obvious } \\
\text { change }\end{array}$ & No obvious change \\
\hline
\end{tabular}

\section{The current study}

In 2003, outside of Asian countries, Canada was hit the hardest by the SARS epidemic. While the death toll seems insignificant compared to that of COVID-19 globally, the outbreak led to several changes in how the government of Canada responded to pandemics. Importantly, Canada created the Public Health Agency of Canada to monitor outbreaks of disease, appointed a Chief Health Officer to advise on health care precautions, prepared a set of guidelines to respond to a pandemic, enhanced research capacity, and improved their working relationship with the World Health Organization (WHO). As COVID-19 started to spread in March of 2020, Canada moved quickly to bring Canadians abroad home, shut down borders, and provide ongoing financial support to Canadians who lost employment. These decisions supported Canadians in staying home and isolating. Additionally, they differ dramatically from the United States, in which leadership made inconsistent decisions and offered few protections to citizens who had lost employment or were unable to access health care. It is likely that these decisions will affect the nature of crime in Canada during the pandemic.

The current study examines crime trends across Vancouver, British Columbia during the initial twelve weeks of the COVID-19 shutdown and compares these trends with projections of previous years. Eight crime types are examined. This is conducted at the city level, in order to explore if the global pandemic is having a city-wide effect. Additionally, 
(a)

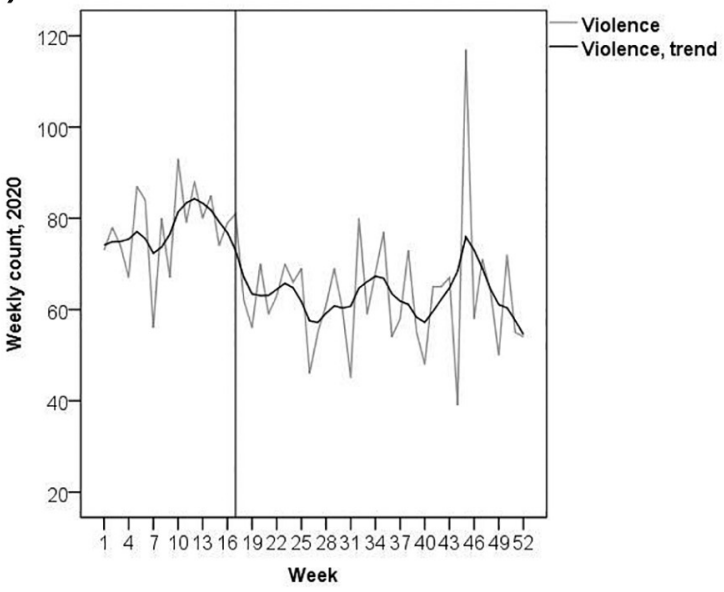

(c)

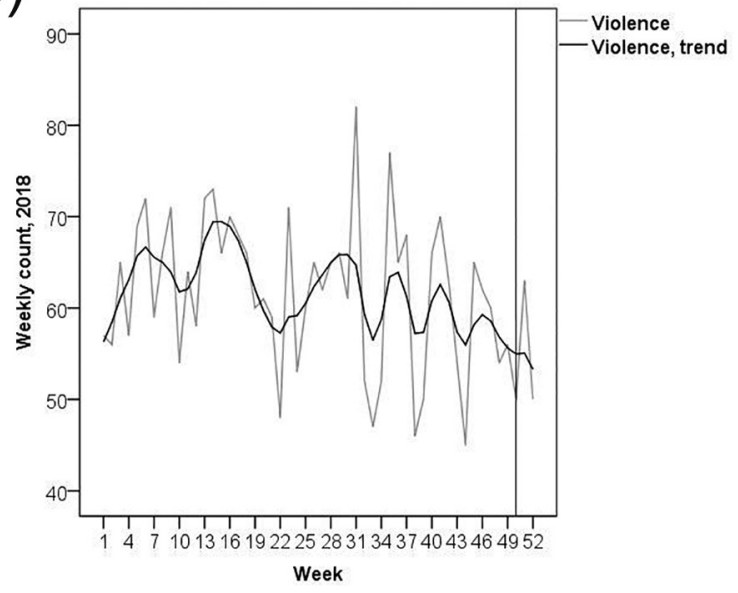

(b)

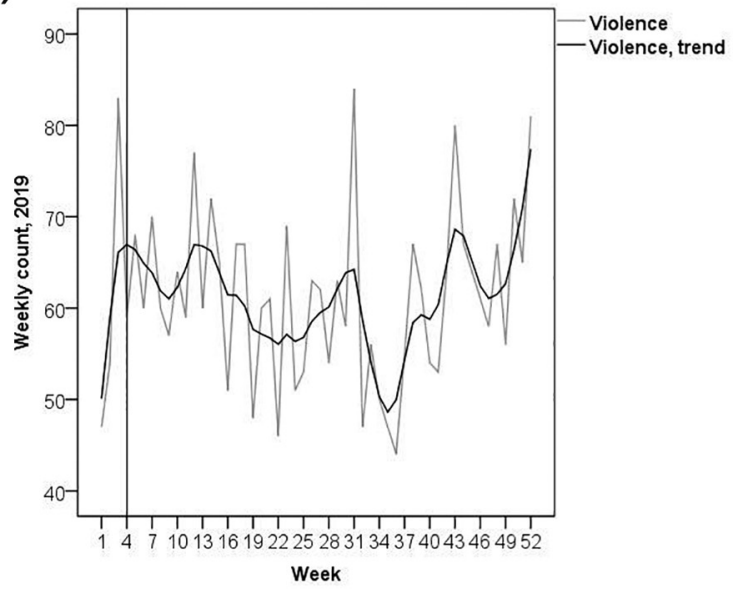

Fig. 3. Vancouver violent crime trends.

most policing services operate at this level and a larger geographic area will be useful for helping to guide practitioners and policy in a rapidly changing environment. We examine eight different crime types as research suggests that different crime types will have different patterns during an exceptional event (Prelog, 2016). We believe these early studies are necessary to inform resource distribution and pandemic response strategies and better aid in a thoughtful and effective recovery.

\section{Data and methods}

The City of Vancouver is part of the Vancouver Census Metropolitan Area (CMA), the third most populated metropolitan area in the country and the most populated in western Canada, had a population of approximately 2.5 million in 2016. Over the past 10 years, 2008-2018, the Vancouver CMA's total crime rate decreased by $22 \%$. However, from the previous year, 2017, the total crime rate in the Vancouver CMA has only decreased by $1 \%$, with an increase in violent crime (4\%) and a decrease in property crime (4\%). Of the three largest metropolitan areas in Canada, the Vancouver CMA had the highest total crime rate (6750 criminal code offenses per 100,000 people). This is slightly more than two times the rate of crime in the Toronto CMA (3428 per 100,000 people) and the Montreal CMA (3275 per 100,000 people). Similar differences are present for property crime, but violent crime is at similar levels for all three CMAs (Moreau, 2019).

The City of Vancouver had a population of approximately 631,000 in 2016, making it the largest municipality within the Vancouver CMA.
Vancouver's total crime rate has only fallen 6\% from 2008 to 2018, currently at 8134 per 100,000 ), approximately double compared to Toronto (4314 per 100,000) and Montreal (3946 per 100,000). However, Vancouver has experienced a notable drop in violent crime over this time period $(29 \%)$ with a more conservative drop in property crime (1\%) at the city level. Vancouver's violent crime rate is similar to that of Toronto and Montreal, but twice the rates of both cities for property crime.

Fig. 1 shows daily COVID-19 infections in British Columbia, most of which occurred in the Vancouver area. Evident from this bar graph is that COVID-19 infections began to rise significantly late February and early March 2020. Daily infections reached their peak by the end of March and have been decreasing, albeit slowly, until the 28th of May 2020.

17 March 2020 is marked on Fig. 1 to indicate changes in routine activities and, therefore, opportunities for criminal activity as that is the day the BC public health emergency was declared, and restrictions began to be put in place. On 14 March 2020, grade school students began spring break and were instructed to not return to school once the break was over. ${ }^{1}$ On 16 March 2020 large gatherings were banned and significant travel restrictions were put in place. On 18 March 2020 the province declared a state of emergency, with restrictions on food and

\footnotetext{
${ }^{1}$ Students in British Columbia returned to the classroom as of June 1, 2020 on an optional and part-time basis. For context, the end of the school year is June 25, 2020.
} 
(a)

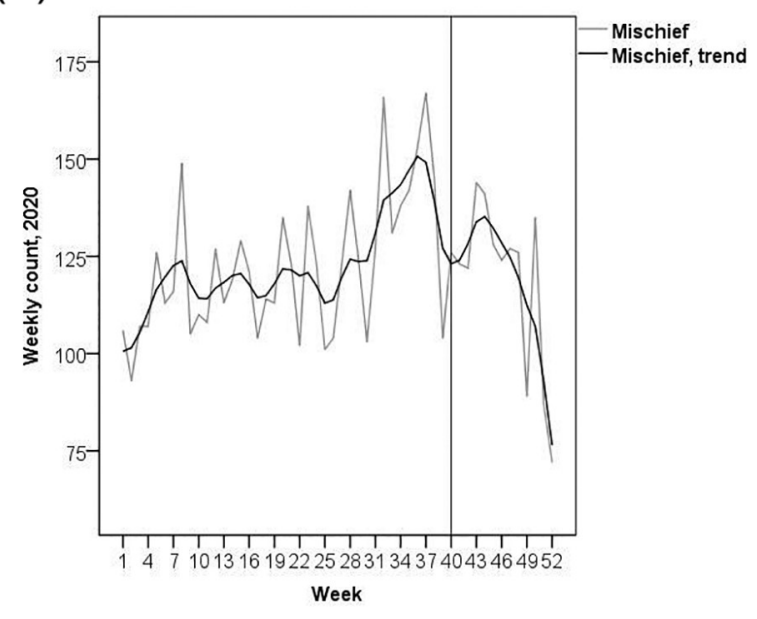

(c)

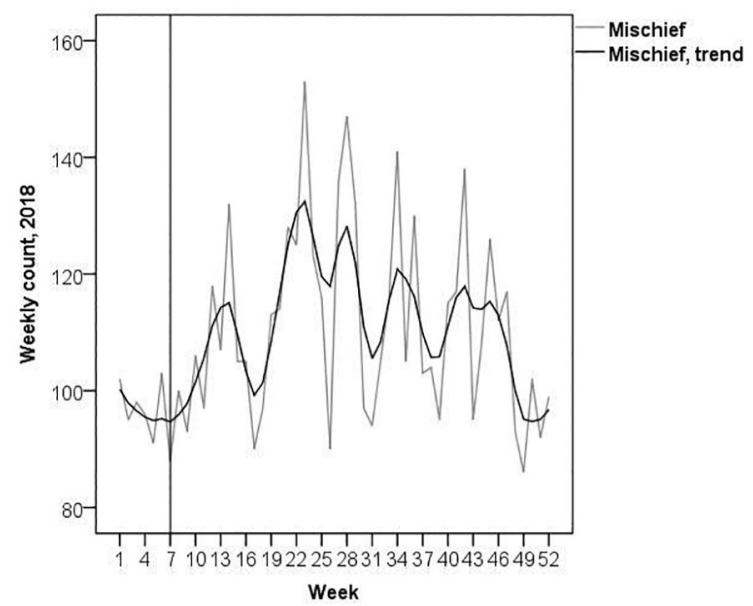

(b)

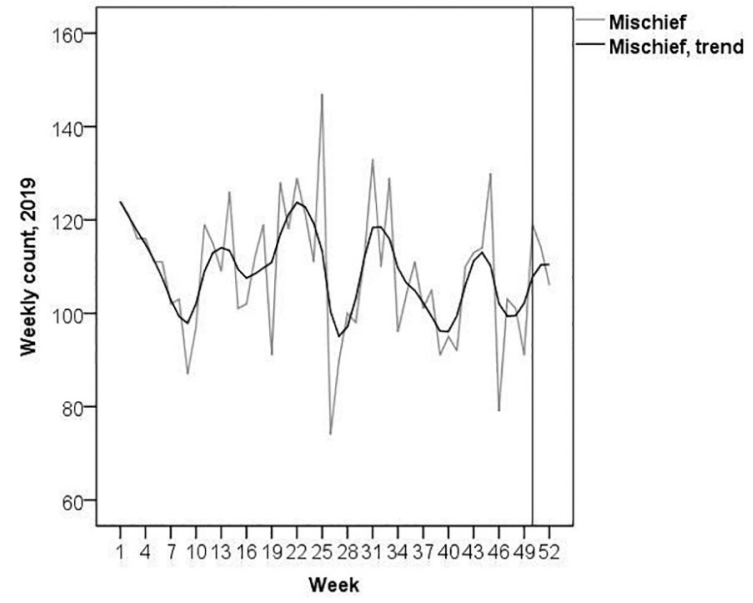

Fig. 4. Vancouver mischief trends.

drink businesses. Finally, on 20 March 2020 the Canada-US international border closed to non-essential travel (BC Centre for Disease Control, 2020).

With the rise of COVID-19 infection rates and public health warnings, followed by significant government policy changes and enactments, we expect any changes in temporal crime patterns to emerge at or around late February and early March 2020 when sharp increases in COVID-19 infections and public health policy changes occurred, consistent with decreases in activity patterns outside of the home (Google, 2020).

\subsection{Crime data}

The current study is a time series analysis of crime at the city level, Vancouver. These data are available from 29 May 2017 to 28 May 2020. The crime incident data used for this study were obtained from the Vancouver Police Department's GeoDash Crime Map website (https://geodash.vpd.ca/). In the analyses below we consider the following crime types: total crime, residential burglary, commercial burglary, theft of vehicle, theft from vehicle, theft, mischief, and violent crime.

\subsection{Analytic plan: Hodrick-Prescott filter and interrupted time series}

Weekly counts of each criminal incident type are used for the analyses to identify any changes in the frequencies related to the timing of COVID-19. In order to identify short-term changes in the volume of criminal incidents in Vancouver, we use weekly crime counts to maximize the number of observations while minimizing volatility. We analyse one year of data, 52 weeks, and search for breaks in the trends of these time series, as outlined below. However, though the time before COVID-19 may serve as a control, and trend-related control variables are used in the analyses, there may be unaccounted for phenomena that occur in March/April/May each year that may make it appear as though a change in trend has occurred when it is simply a recurring annual change in trend. To account for this, we undertake a similar analysis for the 2 previous years to add another dimension of control into our evaluation.

As noted above, weekly criminal incident counts are used in the analyses. However, as seen in the figures below, weekly crime counts are still rather volatile. As such, we use a data smoothing technique to abstract the trend of the data and, subsequently, identify deviations from trend, related to the timing of COVID-19. We use the Hodrick and Prescott (1997) filter to identify the trend component of the time series. Extensively used in the macroeconomics literature, the Hodrick and Prescott (1997) filter separates the trend, cyclical, and error components of a time series:

$y_{t}=\tau_{t}+c_{t}+\epsilon_{t}$

where $y_{t}$ is the time series of interest, $\tau_{t}$ is the trend component, $c_{t}$ is the cyclical component (weekly pattern, for example, and $\epsilon_{t}$ is the error 
(a)

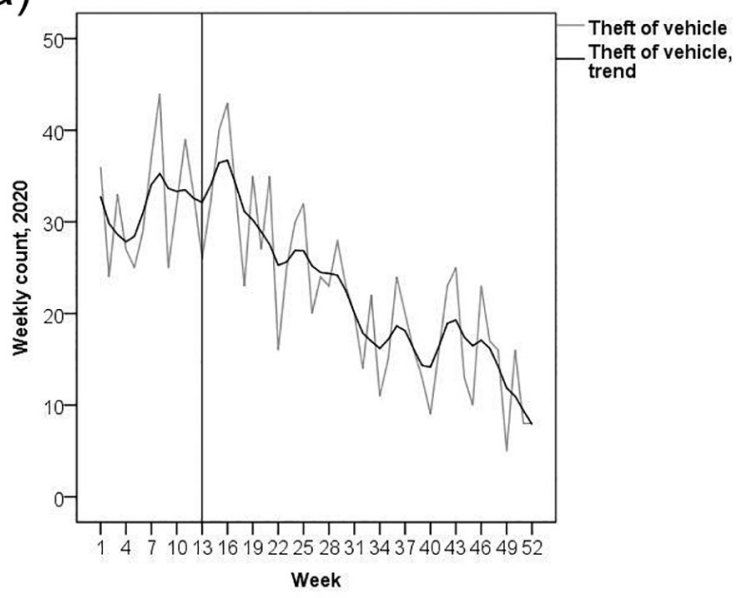

(c)

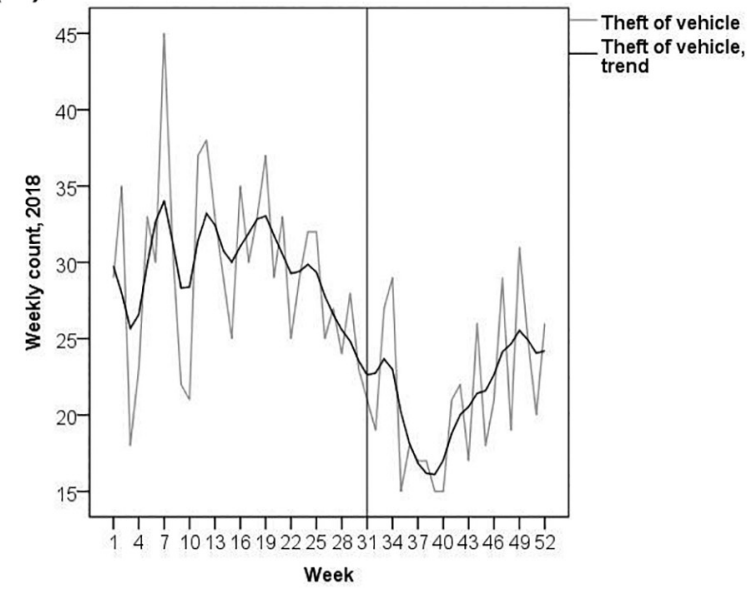

(b)

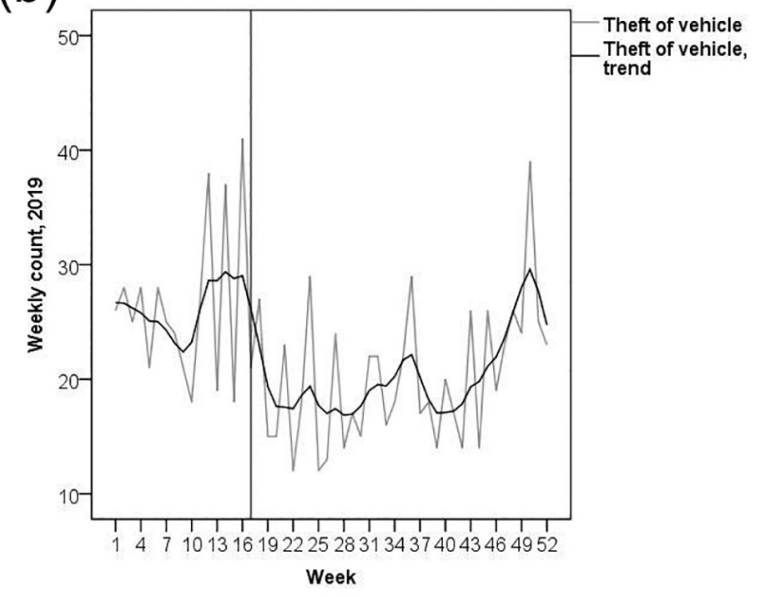

Fig. 5. Vancouver theft of vehicle trends.

component. The trend component, $\tau_{t}$, is identified using the following function:

$\min _{\tau}\left(\sum_{t=1}^{T}\left(y_{t}-\tau_{t}\right)^{2}+\lambda \sum_{t=2}^{T-1}\left[\left(\tau_{t+1}-\tau_{t}\right)-\left(\tau_{t}-\tau_{t-1}\right)\right]^{2}\right)$.

The first term in Eq. (2) is the sum of squared deviations of the original times series and its trend; the second term is the sum of squares of the squared second differences, penalizing variations in the growth rate of $\tau_{t}$. The Hodrick and Prescott (1997) filter can be specified such that it can be used in all temporal frequencies: daily, weekly, monthly, seasonally, annually, and so on. All Hodrick-Prescott filter calculations are undertaken in $\mathrm{R}$ using the mFilter library, developed by Balcilar (2018).

The benefit of using the Hodrick and Prescott (1997) filter is that it smooths/identifies the trend in the data without the loss of observations that occurs when using more traditional methods such as moving average calculations. However, the Hodrick and Prescott (1997) filter is not without its critiques, particularly around its identification and analysis of the cyclical component in a time series (Hamilton, 2018). But because we are not using the Hodrick and Prescott (1997) filter to identify and analyse the cyclical component of times series, but rather smooth volatile (weekly) time series data, is a lesser concern. And the ability to maintain all data points is of particular importance given the recency of potential changes in crime trends.

Interrupted times series is used to identify any changes in the trends of these time series, in conjunction with a Chow (1960) testing methodology. Interrupted time series tests are increasingly being used within the criminological literature to evaluate policy changes and crime reduction programs (Hodgkinson, Andresen, \& Saville, 2018; Piehl, Cooper, Braga, \& Kennedy, 2003; Reid \& Andresen, 2014). Moreover, these tests can be adapted for both known (exogenous) and unknown (endogenous) trend changes. In the current context there is a known policy intervention through the restriction of large gatherings, as discussed above. However, because we do not know how well these restrictions were enforced at their commencement date, 17 March 2020, we use a sequential Chow (1960) test to endogenously search for a change in the trends of the criminal incident types:

$\tau_{t}=\alpha+\beta_{1}$ Week $+\beta_{2}$ Week $^{2}+\gamma_{1}$ Break $+\gamma_{2}$ BreakTrend $+\gamma_{3}$ BreakTrend $^{2}$.

We account for the known seasonal component in crime data (Andresen \& Hodgkinson, 2018; Breetzke \& Cohn, 2012; Cohn \& Rotton, 2000; Farrell \& Pease, 1994; Linning, Andresen, Ghaseminejad, \& Brantingham, 2017; McDowall, Loftin, \& Pate, 2012) through the inclusion of both week and week-squared variables that are represented by sequential values $(1,2,3, \ldots, 52)$ representing the weeks 29 May 2019 to 28 May 2020, for example; the week-squared variable is the square of week, allowing for any seasonality in the data to be identified. These two variables measure the underlying trend in the data.

The interrupted times series (break in trend) variables (break, break trend, and break trend-squared) allow us to identify any changes in the frequency of criminal incidents, as both a sudden increase at the timing of the policy change (break) and changes in the trend at the timing of the policy change (trend and trend-squared). With 52 weekly 
(a)

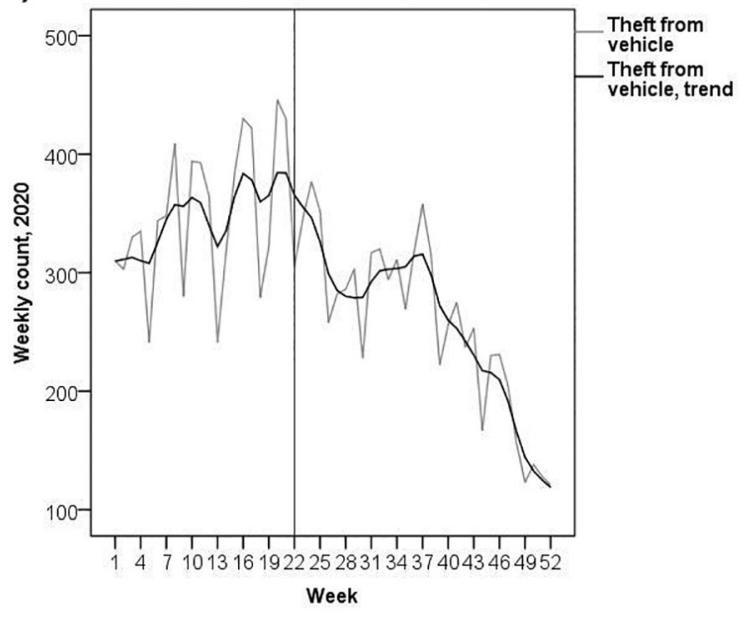

(c)

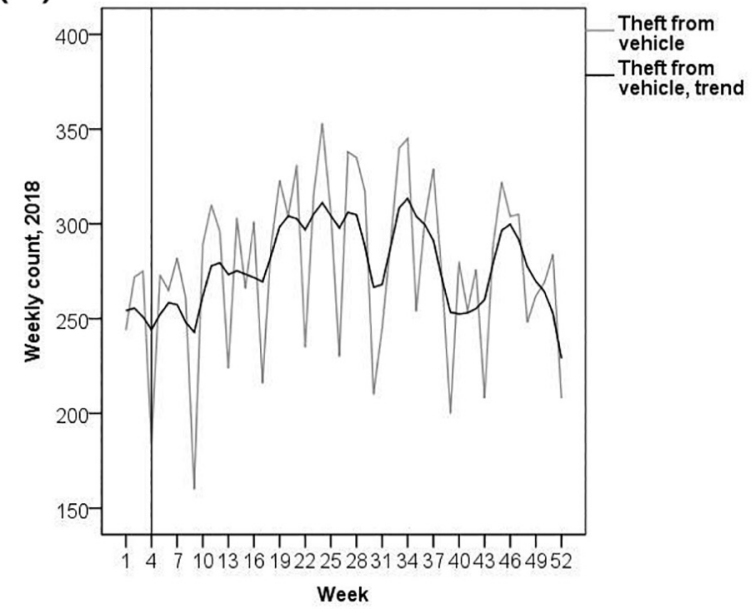

(b)

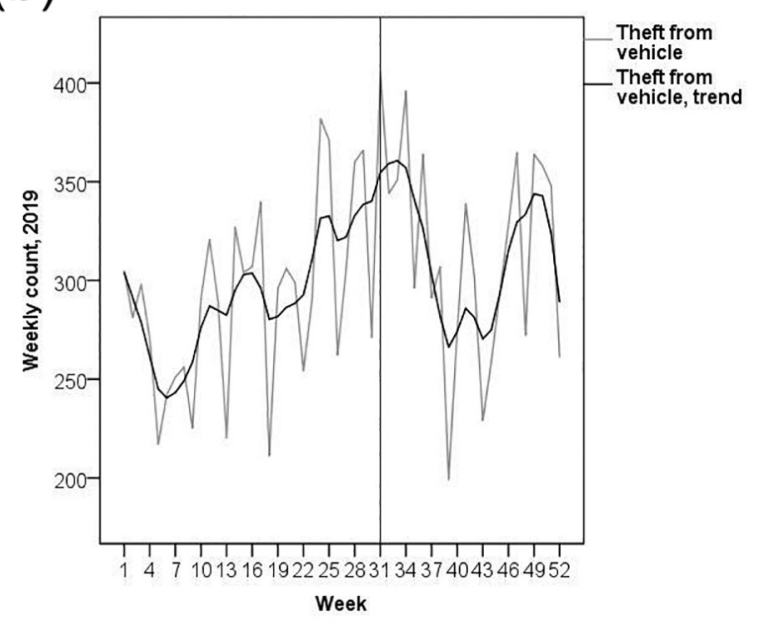

Fig. 6. Vancouver theft from vehicle trends.

observations there are 50 potential break points to identify; however, we exclude the first and last 2 observations in order to facilitate the actual calculation of the break trend variable. As such each break-based variable has the value of zero before its representative break time and unity (break dummy variable) or sequential values (break trend variable) thereafter.

For each of the crime variables (counts of total crime, residential burglaries, commercial burglaries, thefts of vehicle, thefts from vehicles, theft, mischief, and violence), we estimate 48 possible break points. The actual structural breaks are determined at the time period that has the greatest value t-statistics for the break variables using robust standard errors (heteroskedastic and autocorrelation consistent). All estimation for the sequential Chow tests is undertaken using R: A language and environment for statistical computing, version 3.5.3 ( $\mathrm{R}$ Core Team, 2019).

\section{Results}

The weekly time series for the various crime types in Vancouver are shown in Figs. 2-9. All crime types have control years ending 28 May 2018 and 28 May 2019, respectively, in order to identify changes in Vancouver's temporal crime patterns that are not expected. Table 1 summarizes the results from the interrupted times series analyses.

Figs. 2 to 9 show that there is a clear seasonal pattern to crime in Vancouver that is consistent with previous research (Andresen \&
Malleson, 2013, 2015). The seasonal pattern is not as strong as found in some research (e.g. McDowell et al., 2012) but is present, nonetheless. The typical pattern, present for most crime types in most years, is an increase in event frequency during the summer and early fall, with subsequent declines in the winter months. As such, there is an expectation for most crime types to have (moderate) increases in their frequency at the time COVID-19 restrictions were put into place. This is evident (in Figs. 2, 5, 6, and 7) for total crime, theft of vehicle, theft from vehicle, and theft, particularly in 2018. The remaining crime types (violence, mischief, residential burglary, and commercial burglary) exhibit non-obvious or non-notable changes at this time of year given expected seasonal changes. This is not the case, however, for the temporal crime patterns from March to May 2020.

Considering Figs. 2 to 9 and Table 1, there are a number of unexpected changes that occurred in March/April/May 2020 that did not occur in previous years. This is most easily seen in the Hodrick and Prescott (1997) trends, despite the volatility of weekly crime data. What can be seen from these results (graphed data and the breaks in trend identified by the interrupted time series analyses) is that total crime, theft from vehicle, and theft. All present decreasing trends in March/April/May 2020 when they are expected to be increasing or stable during these months. Additionally, theft of vehicle has no obvious change in temporal trend March/April/May 2020 when it would be expected to increase, particularly based on the two most recent previous years. Perhaps most dramatic is the significant increase, and 
(a)

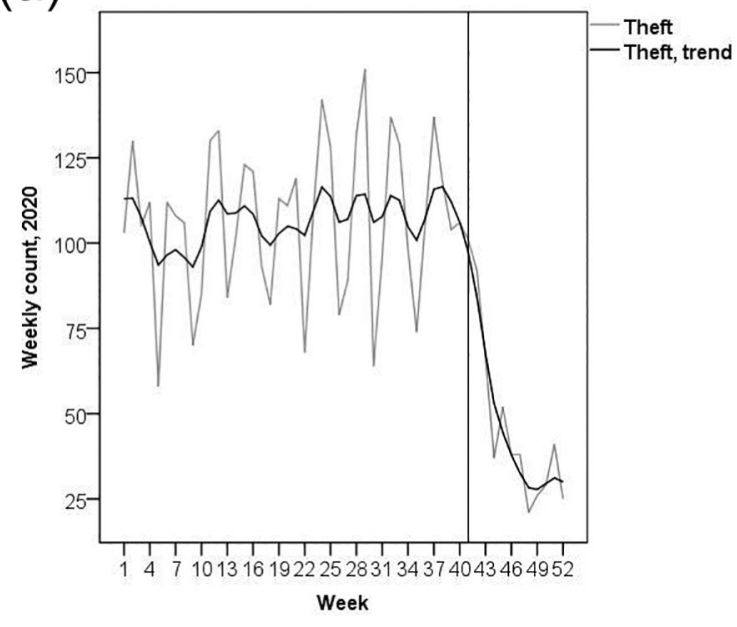

(c)

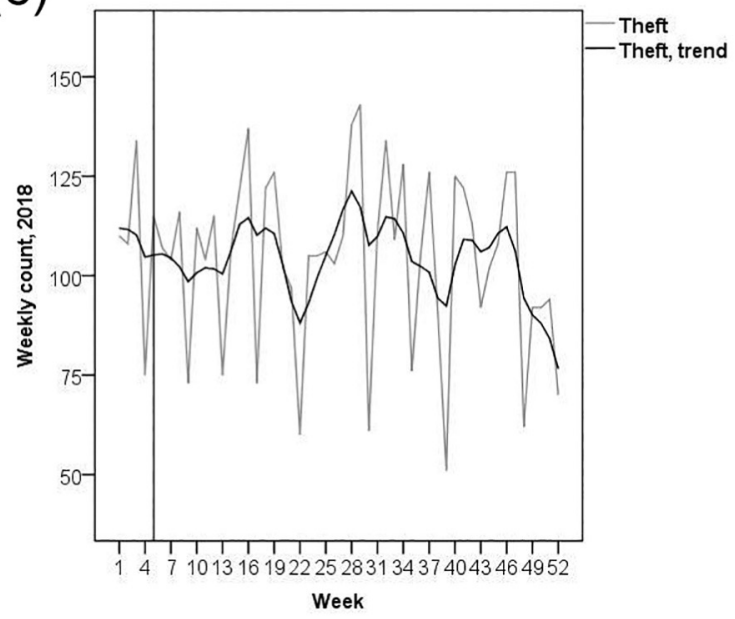

(b)

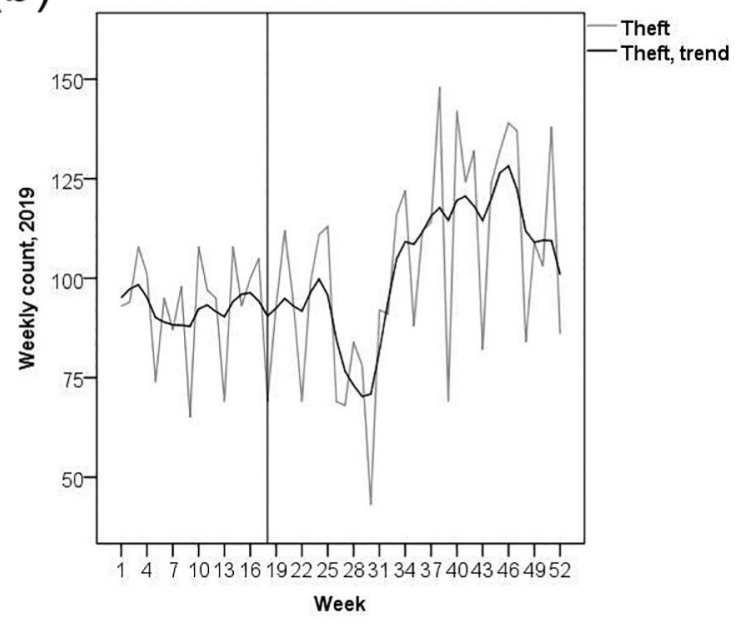

Fig. 7. Vancouver theft trends.

subsequent decrease in commercial burglaries, post-March 2020. Lastly, there are no notable changes in violence or mischief at this time.

Of particular interest is the timing of the breaks in trend identified by the interrupted time series analyses. Because of the volatility of weekly crime data, even those data smoothed by the Hodrick and Prescott (1997) filter, the timing of the breaks in trend are not always at or after week 40 when a public health emergency was declared. For example, in the years ending in 2018 and 2019, see Table 1, breaks in trend have almost no consistency crime type to crime type. However, in the year ending in 2020, there are notable changes in trend that occurred well within the COVID-19 related restrictions in British Columbia when health warnings were underway. Collectively, the consistency in the timing of the breaks in trend and the changes in the expected directions of those trends (a lack of change in trend for the case of theft of vehicle) shows that COVID-19 and its corresponding implications on opportunity structures have had significant impacts on crime in Vancouver.

\section{Discussion}

Consistent with opportunities theories, such as routine activities, the results demonstrate that as the nature of social life shifted into isolation, crime rates fluctuated accordingly. Unlike social cohesion or altruism theories that predict crime would remain stable or decrease, or social disorganization theories that would predict crime would increase, routine activity and opportunity theories suggest that crimes may increase or decrease depending on the opportunity structure and the character of the exceptional event. In Vancouver, we found that there was a significant decrease in total crime, when the previous seasonal patterns suggest we should have found an increase or stability. When we broke that pattern down by crime type, we found that there was a significant increase in commercial burglary, followed by a decrease, when in previous years it remained relatively stable during this time. Theft and theft from vehicle decreased despite typically stable trajectories for these crime types in previous years. Auto theft was stable when it would be expected to be increasing. Violence, mischief, and residential burglary had no obvious change over this time period compared to previous control years.

According to routine activity theory many of these changes in crime trends are unsurprising. As motivated offenders, suitable targets, and a lack of capable guardianship converge differently, crimes trends should fluctuate. For example, commercial burglary increased during the COVID-19 shut down because businesses were forced to close, and owners and employees were no longer present to act as capable guardians. Subsequent decreases would be expected if capable guardians reacted to this shift in crime. In Vancouver, the police responded to the surge in calls for commercial burglary by arresting offenders and urging business owners to increase security - which many did by boarding up their shops (CBC, 2020). This provides not only support for routine activity theory, but also the importance of natural surveillance (Cozens, Saville, \& Hillier, 2005). Theft and theft from vehicle likely declined, and auto theft failed to increase as expected, as suitable targets were 
(a)

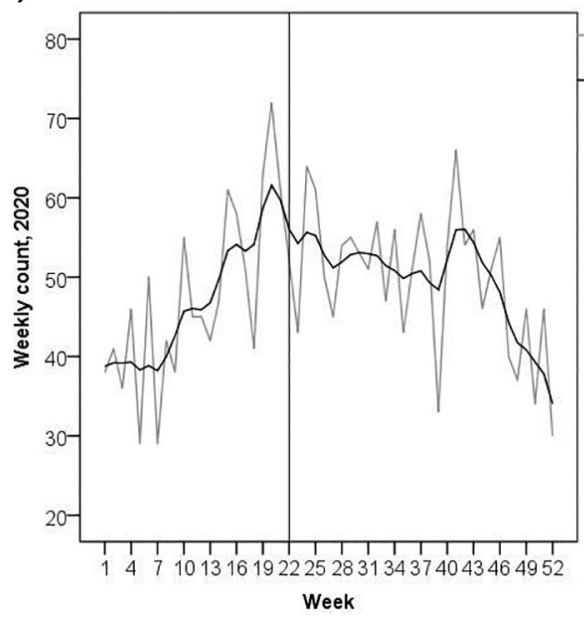

(c)

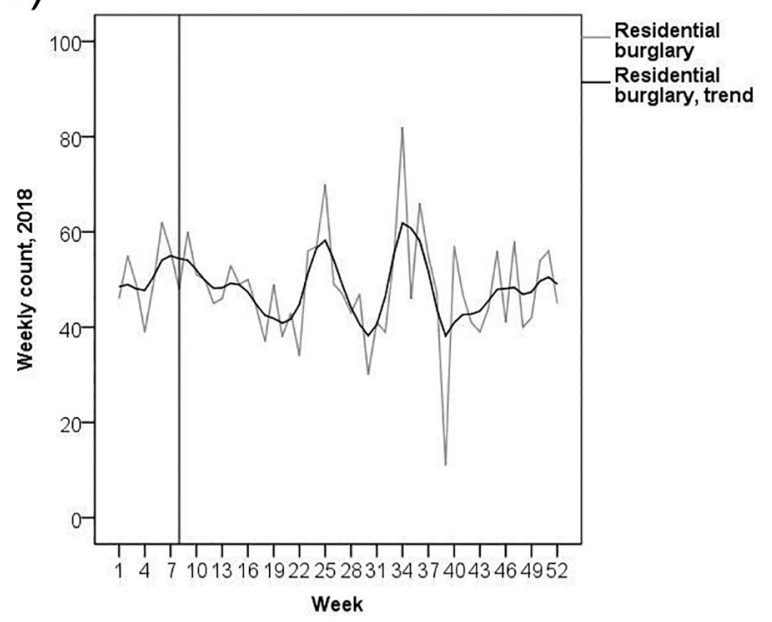

(b)

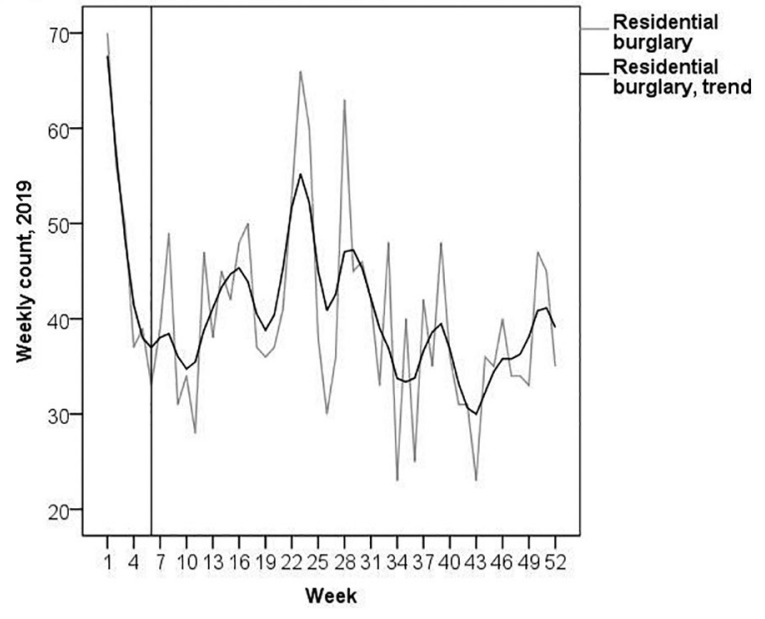

Fig. 8. Vancouver residential burglary trends.

relocated, and capable guardianship increased. For example, it might be more difficult to steal or steal from vehicles that are now parked in the garage of the owner, rather than an above ground parking lot during the workday (Hodgkinson, Andresen, \& Farrell, 2016).

The theory could predict that mischief would increase as young persons have more time outside of school to engage in troublemaking. However, because of the nature of the pandemic restrictions, capable guardianship actually increases as youth are expected by both parents and government officials to not leave the home. If they were witnessed out alone or in a group, this may increase their likelihood of being caught, because this behavior may appear more suspicious. Thus, the findings are consistent with routine activity theory. Counterintuitively, violence and residential burglary trends did not demonstrate a significant change over the study period, aside from expected seasonal patterns, as would be predicted by routine activity theory.

Residential burglary should have witnessed a significant decrease. As residents are home throughout the day, they can act as capable guardians making it very difficult to break in. However, Vancouver had experienced significant declines in residential burglary across all neighborhoods prior to COVID-19 (Hodgkinson \& Andresen, 2019) and, thus, residential burglary counts may have already been too low to demonstrate any change.

Regarding violence, routine activity theory would predict that assault may decline as there are fewer opportunities for motivated offenders and suitable targets to converge in certain locations, such as alcohol outlets (bars, pubs, etc) or schools (fights). At the same time, the theory would predict that domestic assault would increase as offenders and victims are now consistently in the same space without capable guardianship. In our study, rates of violence do not change over the study period. However, violence is a combined measure of all crimes against person. Thus, maintaining its expected seasonal trajectory is unsurprising as the decrease in assault may counter with the expected increase in domestic violence.

It may also be useful to consider that women may be even less likely to report domestic violence if their access to social services in the pandemic is limited. As a result, they would be unlikely to find shelter if reporting leads to an escalation in violence. Unfortunately, the data here do not provide us with the opportunity to explore this issue, but it is an area that desperately needs further attention. Outreach services may be in a better position to understand what is happening in this area and how to address this gendered aspect of community safety during an exceptional event like a pandemic.

Overall, however, the changes in crime trends in Vancouver are consistent with the change in routine activities. We believe this research may be useful in guiding policy and practice. For example, as opportunities for commercial burglary increase, so too must alternative forms of capable guardianship. This may include the police or citizenled patrols. In Vancouver, many businesses boarded up their storefronts to add additional layers of security (Singh \& Chan, 2020). In a more creative response, a local printing shop has encouraged local artists to cover these boarded-up storefronts with art that celebrates front-line workers in order to reduce the "fortress" look of these business areas 
(a)

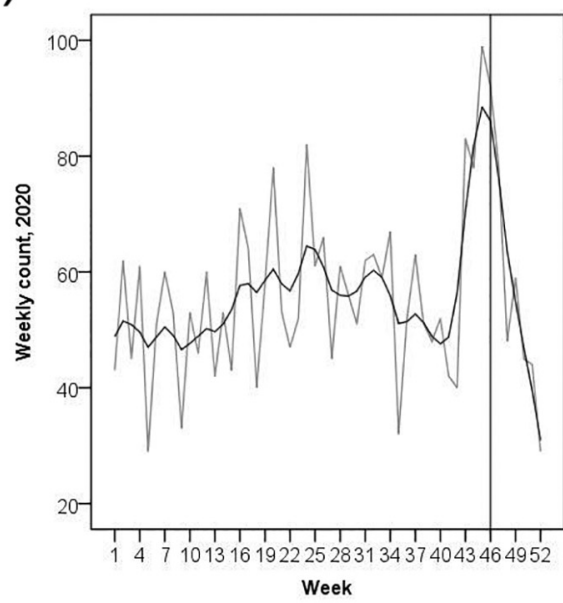

(c)

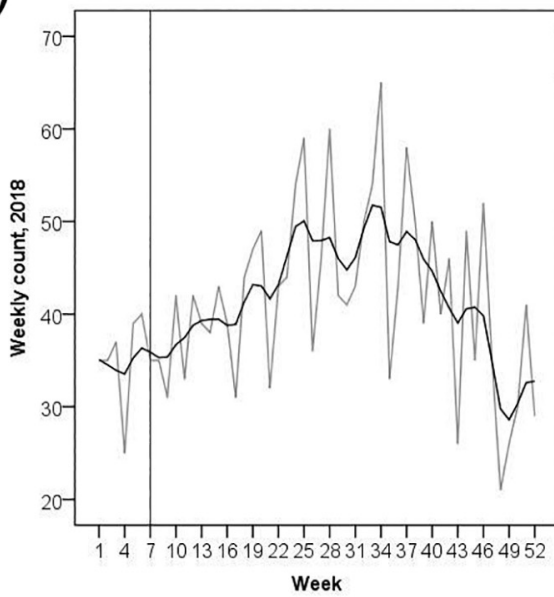

(b)

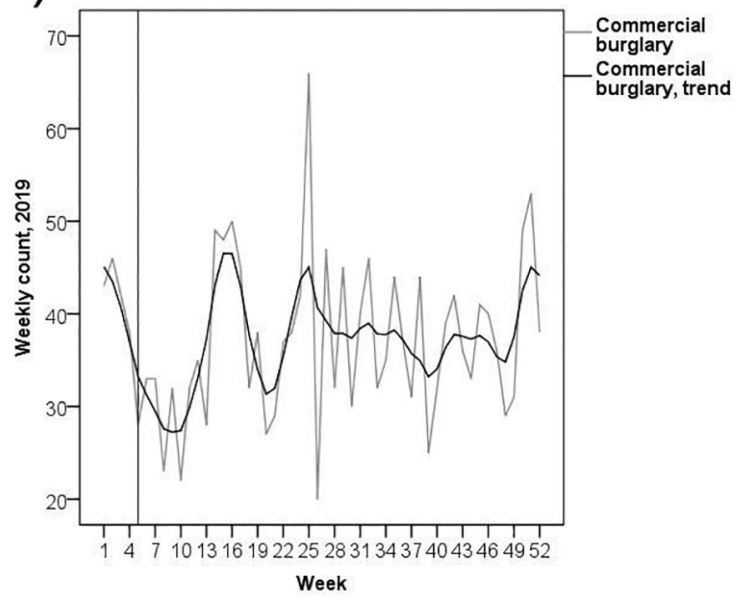

Fig. 9. Vancouver commercial burglary trends.

(Crawford, 2020). As the opportunity structure of crime changes during an exceptional event like a pandemic, it is important to address opportunities for crime early in the outbreak.

\subsection{Limitations}

As with any analysis, ours is not without its limitations. Because of the source of our data, Vancouver Police Department, we are limited to the impact COVID-19 has on criminal incidents reported to the police. Estimates for such reporting are not available at the city level, but in Canada the average reporting rate to the police is $31 \%$ in 2014 (Perreault, 2015), a percentage that has been decreasing since the late1990s (Perreault, 2015; Perreault \& Brennan, 2010). Moreover, reporting rates vary significantly from $5 \%$ (sexual assault) to $50 \%$ (burglary). As such, we cannot know the full impact of COVID-19 on all criminal victimizations. Additionally, the classification for violent crime is not available in a disaggregated format. Because of this, we are not able to differentiate between different violent criminal incidents. In the current context, this could be quite important. As mentioned, with self-isolation and the closure of liquor establishments, we expect decreases in assaults, particularly those related to alcohol (Grubesic \& Pridemore, 2011); similarly, with increased time together coupled with the stress of a pandemic, we expect increases in domestic violence (Parkinson, 2019). Depending on their changes in frequency, one may cancel out the other in the aggregate such that there is no identifiable change overall. However, without disaggregated crime data we cannot assess this possibility.

There are also unknowns at this point in the research. We are unable to say if calls for service and police activity have been affected by the virus. Police may change their behavior to protect themselves from contracting the virus. Furthermore, police may change how they respond to calls as it becomes increasingly irresponsible to arrest and incarcerate people who may then be at an increased risk of contracting the virus. We were unable to explore these changes to police behavior in this study.

Importantly, the research is limited by its focus on the city-level. This means any changes to opportunity structures at the local level, such as shifts in land use, are unable to be investigated here. Additionally, in many countries, academics, legal practitioners, and social workers are demanding de-incarceration and improved housing policies for the homeless, in order to prevent the spread of the virus (Bartels \& Anthony, 2020; Kim, 2020; Kirby, 2020). The changes in land use, coupled with shifts in social policy will likely affect the nature of routine activities at both the local and city levels and require further examination.

\subsection{Future directions}

Directions for future research follow from the limitations outlined above. First, qualitative research that can more thoroughly investigate victimization should be undertaken in order to establish a deeper understanding of the impacts of COVID-19 on criminal victimization. 
Second, research that disaggregates violent crime into its component parts is necessary to identify any changes that are more nuanced than total violent crime. Third, researchers should attempt to obtain and analyse disaggregated data that account for shifts in land use and opportunity structures as a result of local shifts in COVID-19 related policies. And fourth, though the impacts over time of COVID-19 may not be known for some time, continued research in this area should be undertaken to identify medium- and long-term effects, if any, of the pandemic.

We predict that as the pandemic ends, and routine activities return to their pre-pandemic state, so too will crime trends. This will include the return of informal social controls such as the capable guardians of commercial establishments, that have already resulted in decreases in commercial burglary. We expect that other crime types described above such as theft and auto theft will likely return to their previous seasonal trajectories as well. We may witness an increase in cybercrime, as many systems have moved online in order to cope with the crisis and some may remain there. However, as potential victims become more computer savvy, this may actually decrease (e.g potential victims may be become capable guardians).

At the point of writing we do not know how long the pandemic will last. Routine activity theory assumes motivated offenders as a constant. However, as the economy changes, and people are unable to work and become more desperate, it is possible that crime trends may increase to match changes in motivation. There are parts of the world that are suffering already, where staying indoors is not an option and corporations and politicians are beginning to meddle in COVID-19 related decisions (Wilson, 2020). Furthermore, there are certain groups who are already marginalized and struggling who will be affected more deeply by continued restrictions on work and the economy. Indeed, it would be unfair to claim that the shift in routine activities alone may be driving crime rates, when other countries do not experience the same institutionalized altruism from which many Canadians benefit (Lemieux, 1998). Comparative research is necessary to determine if similar social support policies may benefit other countries who are experiencing greater rates of social inequality and, subsequently, increased motivation, during the pandemic. Finally, early and continued methodologically rigorous research is necessary on crime and exceptional events to not only identify how crime is changing, but how to better prevent it.

\section{Conclusion}

Regardless of these limitations, and subsequent directions for future research, we contribute to the literature on exceptional events and crime through the analysis of a (ongoing) pandemic as a natural experiment. Similar to previous research that has investigated the impact of natural disasters on crime, this topic is not to be taken lightly. Rather, given its presence we can use it to better understand social phenomena, hopefully making cities safer during the crisis and in its aftermath. While we have yet to know the full extent of the economic impact globally, with small businesses closing, and people potentially losing their livelihoods, this global pandemic may change the social and demographic nature of the city. This will undoubtedly affect local social processes and likely further affect post pandemic crime trends.

\section{References}

Andresen, M. A., \& Hodgkinson, T. (2018). Evaluating the impact of police foot patrol at the micro-geographic level. Policing: An International Journal, 41(3), 314-324.

Andresen, M. A., \& Malleson, N. (2013). Crime seasonality and its variations across space. Applied Geography, 43, 25-35.

Andresen, M. A., \& Malleson, N. (2015). Intra-week spatial-temporal patterns of crime. Crime Science, 4 (Article 12).

Andresen, M. A., \& Tong, W. (2012). The impact of the 2010 winter Olympic games on crime in Vancouver. Canadian Journal of Criminology and Criminal Justice, 54(3), 333-361.

Ashby, M. P. J. (2020). Initial evidence on the relationship between the coronavirus pandemic and crime in the United States. Crime Science, 9 (Article 6).
Balcilar, M. (2018). mFilter: Miscellaneous time series filters. (R package version 0.1-4).

Barsky, L., Trainor, J., \& Torres, M. (2006). Natural hazards center quick response report number 184. February 2006. Natural Hazards Center, University of Colorado at Boulder.

Bartels, L., \& Anthony, T. (2020). Limited release of prisoners may prevent COVID-19 break out. Retrieved from https://anu.prezly.com/limited-release-of-prisoners-mayprevent-covid-19-break-out?asset_type $=$ attachment\&asset_id $=172138$.

Barton, A. H. (1969). Communities in disaster: A sociological analysis of collective stress situations. Garden City, NY: Doubleday \& Company.

BC Centre for Disease Control (2020). British Columbia COVID-19 daily situation report, April 17, 2020. Vancouver, BC: BC Centre for Disease Control.

Breetzke, G. D., \& Andresen, M. A. (2018). The spatial stability of alcohol outlets and crime in post-disaster Christchurch, New Zealand. New Zealand Geographer, 74(1), $36-47$.

Breetzke, G. D., \& Cohn, E. G. (2012). Seasonal assault and neighborhood deprivation in South Africa: Some preliminary findings. Environment and Behavior, 44(5), 641-667.

CBC (2020, 15 April). 40 arrested as Vancouver sees surge in commercial break-ins since COVID-19 measures began. Retrieved from https://www.cbc.ca/news/canada/ british-columbia/vancouver-commercial-break-ins-covid-19-1.5532001.

Chow, G. C. (1960). Tests of equality between sets of coefficients in two linear regres sions. Econometrica, 28(3), 591-605.

Cohen, L. E., \& Felson, M. (1979). Social change and crime rate trends: A routine activity approach. American Sociological Review, 44(4), 588-608.

Cohn, E., \& Rotton, J. (2000). Weather, seasonal trends and property crimes in Minneapolis, 1987-1988. A moderator-variable time-series analysis of routine activities. Journal of Environmental Psychology, 20(3), 257-272.

Corwin, J. L., \& Miles, W. T. (1978). Impact Assessment of the 1977 New York City Blackout. http://blackout.gmu.edu/archive/pdf/impact_77.pdf.

Cozens, P., Saville, G., \& Hillier, D. (2005). Crime prevention through environmental design (CPTED): A review and modern bibliography. Property Management, 23(5), 328-356.

Craemer, T. (2010). Evaluating racial disparities in hurricane Katrina relief using direct trailer counts in New Orleans and FEMA records. Public Administration Review, 70(3), $367-377$.

Crawford, T. (2020, April 02). COVID-19: Murals honouring health-care workers painted on boarded up Gastown print shop. Retrieved from https://vancouversun.com/news/ covid-19-murals-honouring-health-care-workers-painted-on-boarded-up-gastownprint-shop/.

Cromwell, P., Dunham, R., Akers, R., \& Lanza-Kaduce, L. (1995). Routine activities and social control in the aftermath of a natural catastrophe. European Journal on Criminal Policy, 3(3), 56-69.

Curtis, A., \& Mills, J. W. (2011). Crime in urban post-disaster environments: A methodological framework from New Orleans. Urban Geography, 32(4), 488-510.

Curtis, T., Miller, B. C., \& Berry, H. E. (2000). Changes in reports and incidence of child abuse following natural disasters. Child Abuse Neglect, 24(9), 1151-1162.

Davila, M., Marquart, J., \& Mullings, J. (2005). Beyond mother nature: Contractor fraud in the wake of natural disasters. Deviant Behavior, 26(3), 271-293.

Drabek, T. (1986). Human system responses to disaster: An inventory of sociological findings. New York, NY: Springer-Verlag.

Eisner, M., \& Nivette, A. (2020). Violence and the pandemic: Urgent questions for research. New York, NY: Harry Frank Guggenheim Foundation.

Farrell, G., \& Pease, K. (1994). Crime seasonality: Domestic disputes and residential burglary in Merseyside 1988-90. British Journal of Criminology, 34(4), 487-498.

Farrell, W. E. (1965). The morning after. In S. J. Bhm, L. Foster, \& B. G. G. Slosser (Eds.). The night the lights went out (pp. 48-66). New York, NY: Signet.

Felson, M., \& Cohen, L. E. (1980). Human ecology and crime: A routine activity approach. Human Ecology, 8(4), 389-405.

Fothergill, A., \& Peek, L. A. (2004). Poverty and disasters in the United States: A review of recent sociological findings. Natural Hazards, 32(1), 89-110.

Genevie, L., Kaplan, S. R., Peck, H., Struening, E. L., Kallos, J. E., Muhlin, G. L., \& Richardson, A. (1987). Predictors of looting in selected neighbourhoods of new York City during the blackout of 1977. Sociology and Social Research, 71, 228-231.

Google (2020, April 17). COVID-19 community mobility report. Retrieved from https:// www.google.com/covid19/mobility/.

Grubesic, T. H., \& Pridemore, W. A. (2011). Alcohol outlets and clusters of violence. International Journal of Health Geographics, 10(1) (Article 30).

Hamilton, J. D. (2018). Why you should never use the Hodrick-Prescott filter. Review of Economics and Statistics, 100(5), 831-843.

Harper, D. W., \& Frailing, K. (2012). Crime and criminal justice in disaster. Durham, NC: Carolina University Press.

Hodgkinson, T., \& Andresen, M. A. (2019). Changing spatial patterns of residential burglary and the crime drop: The need for spatial data signatures. Journal of Criminal Justice, 61, 90-100.

Hodgkinson, T., Andresen, M. A., \& Farrell, G. (2016). The decline and locational shift of automotive theft: A local level analysis. Journal of Criminal Justice, 44(1), 49-57.

Hodgkinson, T., Andresen, M. A., \& Saville, G. (2018). "Staying out that public housing": Examining the role of security measures in public housing design. Crime Prevention \& Community Safety: An International Journal, 20(2), 99-112.

Hodrick, R., \& Prescott, E. C. (1997). Postwar U.S. business cycles: An empirical investigation. Journal of Money, Credit, and Banking, 29(1), 1-16.

Kim, C. (2020, April 03). Why people are being released from jails and prisons during the pandemic. Retrieved from https://www.vox.com/2020/4/3/21200832/jail-prisonearly-release-coronavirus-covid-19-incarcerated.

Kirby, T. (2020). Efforts escalate to protect homeless people from COVID-19 in UK. The Lancet. https://doi.org/10.1016/S2213-2600(20)30160-0.

Klein, N. (2007). The shock doctrine: The rise of disaster capitalism. New York, NY: Picador. 
Kwanga, G. M., Shabu, T., \& Adaaku, E. M. (2017). Natural disasters and crime incidence: A case of 2012 flooding in Benue state, Nigeria. International Journal of Geology, Agriculture and Environmental Sciences, 5(5), 43-48.

LeBeau, J. L. (2002). The impact of a hurricane on routine activities and on calls for police service: Charlotte, North Carolina, and hurricane Hugo. Crime Prevention and Community Safety: An International Journal, 4(1), 53-64.

Leitner, M., Barnett, M., Kent, J., \& Barnett, T. (2011). The impact of hurricane Katrina on reported crimes in Louisiana: A spatial and temporal analysis. The Professional Geographer, 63(2), 244-261.

Leitner, M., \& Helbich, M. (2011). The impact of hurricanes on crime: A spatio-temporal analysis in the City of Houston, TX. Cartography and Geographic Information Science, $38(2), 213-221$.

Lemieux, F. (2014). The impact of natural disaster on altruistic behaviour and crime. Disasters, 38(3), 483-499.

Linning, S. J., Andresen, M. A., Ghaseminejad, A. H., \& Brantingham, P. J. (2017). Crime seasonality across multiple jurisdictions in British Columbia, Canada. Canadian Journal of Criminology and Criminal Justice, 59(2), 251-280.

Martin, J. (2020, March 16). Trump to governors on ventilators: 'Try getting it yourselves'. Retrieved from https://www.nytimes.com/2020/03/16/us/politics/trumpcoronavirus-respirators.html.

McDowall, D., Loftin, C., \& Pate, M. (2012). Seasonal cycles in crime, and their variability. Journal of Quantitative Criminology, 28(3), 389-410.

Mohler, G., Bertozzi, A. L., Carter, J., Short, M. B., Sledge, D., Tita, G. E., ... Brantingham, P. J. (2020). Impact of social distancing during COVID-19 pandemic on crime in Los Angeles and Indianapolis. Journal of Criminal Justice. https://doi.org/10.1016/j. jcrimjus.2020.101692.

Montgomery, P. L. (1965). And everything was gone. In S. J. Bhm, L. Foster, \& B. G. G. Slosser (Eds.). The night the lights went out (pp. 17-32). New York, NY: Signet.

Moreau, G. (2019). Police-reported crime statistics in Canada, 2018. Ottawa, ON: Statistics Canada.

Neate, R. (2020, March 28). Jeff Bezos sold \$3.4bn of Amazon stock just before Covid-19 collapse. Retrieved from https://www.theguardian.com/business/2020/mar/27/jeffbezos-sold-34bn-of-amazon-stock-just-before-covid-19-collapse.

North, A. (2020, March 17). Millions of American workers are left out of the coronavirus paid leave bill. Retrieved from https://www.vox.com/2020/3/17/21183388/ coronavirus-paid-sick-leave-family-covid-19.

Parkinson, D. (2019). Investigating the increase in domestic violence post disaster: An Australian case study. Journal of Interpersonal Violence, 34(11), 2333-2362.

Perreault, S. (2015). Criminal victimization in Canada, 2014. Ottawa, ON: Statistics Canada.

Perreault, S., \& Brennan, S. (2010). Criminal victimization in Canada, 2009. Ottawa, ON: Statistics Canada.
Piehl, A. M., Cooper, S. J., Braga, A. A., \& Kennedy, D. M. (2003). Testing for structural breaks in the evaluation of programs. Review of Economics and Statistics, 85(3), 550-558.

Prelog, A. J. (2016). Modeling the relationship between natural disasters and crime in the United States. Natural Hazards Review, 17(1) (Article 04015011).

Quarantelli, E. L. (2007). The myth and realities: Keeping the looting myth in perspective. Natural Hazards Observer, 31(4), 2-3.

R Core Team (2019). R: A language and environment for statistical computing. Vienna, Austria: R Foundation for Statistical Computing. URL http://www.R-project.org/.

Readfern, G. (2020, April 15). How did coronavirus start and where did it come from? Was it really Wuhan's animal market? Retrieved from https://www.theguardian. com/world/2020/apr/15/how-did-the-coronavirus-start-where-did-it-come-fromhow-did-it-spread-humans-was-it-really-bats-pangolins-wuhan-animal-market.

Reid, A. A., \& Andresen, M. A. (2014). An evaluation of CCTV in a car park using police and insurance data. Security Journal, 27(1), 55-79.

Ritchie, L. A., \& Gill, D. A. (2011). Considering community capitals in disaster recovery and resilience. PERI symposium: Community recovery from disaster.

Robinson, J. (1933). The economics of imperfect competition. London: Macmillan.

Siegel, J. M., Bourque, L. B., \& Shoaf, K. I. (1999). Victimization after a natural disaster: Social disorganization or community cohesion? International Journal of Mass Emergencies and Disasters, 17, 265-294.

Singh, S., \& Chan, K. (2020, March 29). Downtown Vancouver shops are boarding up their storefronts. Retrieved from https://dailyhive.com/vancouver/downtownvancouver-shops-boarded-up-break-ins-coronavirus.

Sweet, S. (1998). The effect of a natural disaster on social cohesion: A longitudinal study. International Journal of Mass Emergencies and Disasters, 16, 321-331.

Tipson, F. S. (2013). Natural disasters as threats to peace, special report 324. Washington, DC: United States Institute of Peace.

Varano, S. P., Schafer, J. A., Cancino, J. M., Decker, S. H., \& Greene, J. R. (2010). A tale of three cities: Crime and displacement after hurricane Katrina. Journal of Criminal Justice, 38(1), 42-50.

Webster, P. (2020). Canada and COVID-19: Learning from SARS. The Lancet, 395(10228), 936-937.

Wilson, J. (2020, April 17). The rightwing groups behind wave of protests against Covid 19 restrictions. Retrieved from https://www.theguardian.com/world/2020/apr/17/ far-right-coronavirus-protests-restrictions.

Zahnow, R., Wickes, R., Haynes, M., \& Corcoran, J. (2017). Disasters and crime: The effect of flooding on property crime in Brisbane neighborhoods. Journal of Urban Affairs, 39(6), 857-877.

Zahran, S., Shelly, O. T., Peek, L., \& Brody, S. D. (2009). Natural disaster and social order: Modelling crime outcomes and disasters in Florida. International Journal of Mass Emergencies and Disasters, 27(1), 26-52. 